\title{
Heredity in the Criminalization Process of an Individual
}

\author{
Andrejs Vilks* \\ Faculty of Law, Riga Stradiņš University, Latvia
}

*Corresponding author: Andrejs Vilks, Faculty of Law, Riga Stradiṇš University, Latvia.

Received Date: May 09, 2019

Published Date: May 14, 2019

\begin{abstract}
The article discusses the model of the individual's criminalization process, considering the possible socially negative heredity at the genetic level, starting from the antenatal (pre-natal) development period to fixed criminal activities. The performed neurological studies using positron emission tomography in a criminological context confirm the correlation between the potential pathology of the brain of individuals and criminal behavior. Specialist studies may affect the legal framework of legal proceedings, the inclusion of crime subjects and the organization of individual preventive measures.
\end{abstract}

Keywords: Heredity; Criminology; Crime; Criminal; Neurocriminology

\section{Introduction}

Various approaches may identify factors determining crime and the criminal activity of individuals. One of such approaches, which was the basis for the development of positivist criminology, was the focus on the personality of the criminal, his physical and psychosocial peculiarities. Robert M Young, FJ Gall, Lombrozo C [1-3] approaches, which opened new perspectives for criminology, have been cruelly criticized for decades. However, with regard to new personality cognitive methods and innovative technologies, crime determinants, and even more, the role of the primary source of criminalization of the individual is transparent. It is done successfully by a number of psychologists, criminologists, psychiatrists.

The traditional sociological (anomia [4], conflict [5], subcultures [6], social control [7], etc.), as well as new modified theories (public choices [8], public communication crises [9], etc.) (approaches) are sufficiently important and justified in the statement of the individual's criminalization process. Rational justification for this is unquestionable, because the individual is formed, develops and functions in society, expresses his / her attitudes and performs activities in accordance with the requirements of social and legal norms. The conditions of operation and regulation of the society are performed by the relevant institutions. The function of reward and punishment is also a public competence.

In this context, the importance of an individual's heredity and genetic program is sufficiently distant from social reflections, however, it does not necessarily mean leveling the role of heredity in the manifestations of deviant and criminal behavior. Undoubtedly, heredity plays an important role in the expression of the individual's greatness and creativity. In order for a genius and talent (positive deviation) to manifest itself, the necessary favorable environmental conditions are needed. However, the environment is decisive if certain individuals do not have inborn and inherited high intellectual and creative traits.

Equally, from a criminological point of view, the question is whether inheritance can determine the possibilities and manifestations of the criminal development of individuals? In recent years, the investigation of criminal activities has rightly focused on the study of the psychophysiological, nervous, and brain characteristics of criminals. Such an approach reflects the fact that the fundamental factor of criminal behavior (the epicenter of individual criminal behavior) is being researched. It is possible to use the latest medical and psychophysiological research methodology and technologies.

\section{The importance of heredity in an individual's development}

There is no widespread discussion going on that children from their parents inherit the peculiarities of the constitutional structure of the body, the shape of the head, the contours of the facial features, the color of the eyes and hair, etc. There are also good opinions about the fact that children also inherit various 
factors related to health risks and potential illnesses from parents [10-12] Children with parents have many factors in common, including their genes, environment and lifestyle. Parental medical history can identify children with possible more frequent disorders such as heart disease, high blood pressure, stroke, some types of cancer, and diabetes [13].

Do congenital genes also transfer social information-can we recognize a socio-genetic heritage? Genetic variation influences brain function and social behavior. Genes do not specify behavior directly, but rather encode molecular products that build and govern the functioning of the brain through which behavior is expressed. The inherited social information can affect the expression and behavior of brain genes. The fundamental question is not only that social information is passed on genetically to the offspring (children), but what is the content of that information? What is encoded in information? By studying bibliographically, the personalities of different categories of criminals, the author admits that such traits as selfishness, aggression, passivity, greed, revenge, etc. are genetically inherited.

Considering the sufficiently great importance of society and family for the individual in his/her process of formation, the question arises-whether genetic information of unfavorable content is transformed and transformed with positive content. There might be some possibilities for correction if the infant and the child are permanently and constantly placed in a prosocial environment, where he/she is cared for and brought up in a loving environment. The baby is removed from the socially disadvantaged family and later adopted and grows in a secured and favorable environment. However, such trends in personal development, retrospectively analyzing the genders of criminal careers, are rare. Next, we will focus on the importance of heredity in a person's criminal development model.

Infant and baby development can be divided into several stages. On the 23rd day of pregnancy, the heart of the child starts to beat, and the baby is about five mm long. Nerve cells and the brain grow intensively. During the 24-27th weeks of embryonic development, he has periods of sleep and waking. The child starts responding to the surrounding sounds, his weight is around a kilo, length-37cm. From the 30th to 40th week of pregnancy the baby is active. A baby is taking on weight, growing, and developing like a new personality. During this period, the development of the baby is entirely determined by the inherited genetic information.

The trend of criminal development is also influenced by the mother's condition, behavioral characteristics and environmental conditions, which in many cases are not the best (relationship with the child's father, conflicting environment, ambivalent lifestyle, not always sufficient material provision, nutrition adequacy for the baby's normal development, etc. - not essential favorable factors for child development. Let us note that the social environment has not changed dramatically since the birth of the child. During this period, the child's social, emotional, psychological and intellectual potential has increased significantly. In view of the unfavorable genetic social information, this potential has not been transformed with a very positive content. It has become more diverse and saturated.

During the next child development period (about a year) his individual activities are limited and subject to parental care. They are mainly implemented in a local, limited environment where parents live. They are limited and minimal in the mechanism of criminal development of individuals. Not only does the child develop and his personality is formed, according to the reflexive genetically inherited information, but he also has choices of behavioral patterns that are relevant and pleasing to him (games and attitudes towards them, forms of communication with the closest people, positive or contradictory emotions, hyperactivity, etc.) ). The foundation of personality development is created.

In the next child's development period, he/she has a much wider area and range of manifestations and activities. The child chooses more targeted activities, resources (games), friends. Relevant expressions are based on genetically inherited information, which is accordingly enriched in the child's previous stages of development. It is unlikely that the child will leave the programmed segment in its development trend. However, such a possibility must be considered, because not all children, born and raised in a socially disadvantaged environment, further develop a criminal career. However, perhaps, the criminal activities have been identified and have remained latent.

\section{The latest studies in neurocriminology field}

The well-known psychologist and neurocriminologist Adrin Raine, using Positron Emission Tomography (PET), conducted a test with 41-killer and 41 law-abiding control groups [14]. Measuring activity in brain areas it was found that murderers in the frontal brain lobe had lower activity, asking different questions compared to the control group. In response to the questions asked by the experimenters, there was a high activity in the frontal brain lobe of the control group. The study concluded that just the lack of activity of the brain, the inactivity of the control mechanisms, the increased dependence on instincts and external irritants, emotionality promotes non-motivated and elevated aggressiveness. Adrian Raine also concluded that brain scan can identify children who may become murderers in the future [15]. In their study on Philadelphia children with slow physical reactivity associated with deviant behavior, they are prescribed a diet rich in omega-3 fatty acids and calcium. In perspective they might find whether by such an approach the brain cells can be protected. He admits that at least $50 \%$ of the relevant trends can be attributed to genetics. In his wellknown monograph "The Anatomy of Violence: The Biological Roots of Crime (2014), he presents the growing body of evidence that shows how genetics and the environment can create the so-called 'criminal brain' [16].

Tim Adams also admits that people are not free-thinking, rational, as they would like to imagine, i.e. being completely free of restrictions [17]. Human behavior is determined by hereditary genes and neuroanatomy. In these cases, one can talk about crime as 
a biological disease. One can agree that violent crime can be largely determined by the inherited psychophysiological characteristics of individuals, the genetic heritage. Thus, the question of the criminal responsibility and punishment of persons who have committed crimes, including murder, is rightly justified. Only those who are aware of their actions and the consequences that are rational enough may be punished [18].

There are certain cases in the proceedings where the perpetrators of the criminal offense have been acquitted. In 2004, a summary of neuroscience and evidence in criminal law was compiled in the United States (An Overview of the Impact of Neuroscience in Criminal Law.) [19]. It is recognized in the summary that US courts increasingly use brain scan documents as a scientific justification for the guilt or innocence of participants in the proceedings.

In the "United States v. Erskine," (United States vs. Erskine; 588 F, 2d, 721, 9th Cir., 1978), Erskin was accused of giving false testimony to a territorial insurance bank [20]. The US Court of Appeal allowed the later addition of Erskin's brain scan results and the court's decision was reviewed. Such an approach might be justified, but individuals with psychopathological features would need special treatment. [21] In such cases it may be possible to have clinical therapy and the application of forced medical means (inpatient or outpatient treatment). The experience of certain countries in cases of sexual abuse of chemical [22] or surgical castration (Czech Republic) is known. Neurocriminologist A, Raine predicts that by 2034 , the basis for preventing crime will be a neurocriminological approach [16]. We hope that there will be an opportunity to find out if this approach is correct.

\section{Conclusion}

The model of the individual's criminalization process is based on the socially negative heredity that is contained in the information at the genome level. Genetically inherited characteristics such as selfishness, aggression, passivity, the vengeance is inherited. Children, beginning with the antenatal (pre-natal) developmental period to the fixed criminal activities, are formed according to the programmed genetic information. The social environment that could bring about the correction of the formation of individuals is not sterile and highly prosocial. Neurocriminological research suggests that it is the lack of activity of the brain, the inactivity of the control mechanisms, the increased dependence on instincts and external irritants, the emotionality that promotes non-motivated and elevated aggressiveness that can form the "criminal brain". The question of personalized guilt and criminal responsibility of these individuals is debatable. Neurocriminology and neurolaw could play a more prominent role in crime prevention.

\section{Acknowledgement}

None.

\section{Conflict of Interest}

No conflict of interest.

\section{References}

1. Robert M Young, Gall FJ.

2. FJ Gall and phrenology's contribution to neurology.

3. Lombrozo C (1891) The Man of Genius.

4. Durkheim É, Luks S, WD Halls (1982) The Rules of Sociological Method. New York, Free Press, USA.

5. Merton RK (1938) Social Structure and Anomie. American Sociological Review 3(3): 672-682.

6. Huntington S (2014) Subcultures and Social Media. Mass Differentiation.

7. Hirschi T (1969) Causes of Delinquency. Berkeley, University of California Press, USA.

8. Buchanan James McGill Jr (1958).

9. Coombs WT (2007a) Crisis management and communications.

10. Why is it important to know my family medical history?

11. Honor Whiteman Children inherit around 40 percent of parents BMI (2017).

12. Genetic inheritance.

13. Stacey Colino Six health problems your child may inherit from you.

14. Raine A, Buchsbaum M, LaCasse L (1997) Brain abnormalities in murderers indicated by positron emission tomography. Biol Psychiatry 42(6): 495-508.

15. Josh Fischman (2011) Criminal Minds.

16. Raine A (2014) The Anatomy of Violence: The Biological Roots of Crime. New York, NY, USA.

17. Tim Adams (2013) How to spot a murders brain.

18. Kent A (2017) Kiehl A Mind of Crime.

19. (2004) An Overview of the Impact of Neuroscience in Criminal Law.

20. Glimcher PW (2008) The neurobiology of individual decision making, dualism, and legal accountability. In: Engel C, Singer W (Eds.), Better Than Conscious? Implacations for Performance and Institutiona Analysis, Strüngmann Forum Report 1, Cambridge, MA, MIT, USA, pp: 341.

21.Vilks Andrejs (2015) Psycho and Neuro-technology and Public Safety Problems.

22. Amlin K (2013) Chemical Castration: The Benefits and Disadvantages Intrinsic to Injecting Male Pedophiliacs with Depo-Provera. 